\title{
Economic analysis of water production from atmospheric air using Scheffler reflector
}

\author{
Shobhit Srivastava ${ }^{1} \cdot$ Avadhesh Yadav $^{1}$
}

Received: 3 July 2018 / Accepted: 22 November 2018 / Published online: 3 December 2018

(c) The Author(s) 2018

\begin{abstract}
In this paper, the economics analysis of water production by using different solid desiccant materials and composite materials through Scheffler reflector is presented. The experiments for water production have been performed at National Institute of Technology, Kurukshetra, Haryana, India [29 ${ }^{\circ} 58^{\prime}$ (latitude) North and 76 ${ }^{\circ} 53^{\prime}$ (longitude) East]. The various factors have been carried out to calculate the annual cost/liter in Indian currency. Total six cases are studied, and for each case, uniform procedure is adopted. The silica gel gives the best economical annual cost/liter compared to molecular sieve and activated alumina in case of solid desiccant, and for composite material, it is $\mathrm{CaCl}_{2} / \mathrm{River}$ Sand compared to $\mathrm{LiCl} / \mathrm{River}$ Sand and $\mathrm{LiBr} / \mathrm{River}$ sand.
\end{abstract}

Keywords Economic analysis $\cdot$ Water production $\cdot$ Scheffler reflector $\cdot$ Desiccant material

\section{List of symbols}

A Initial cost of the system

$S \quad$ Salvage value

$n \quad$ Useful life of the system

$i \quad$ Annual interest rate

CRF Capital recovery factor

SFF Sinking fund factor

\section{Introduction}

Water is the prime element to sustain life on earth, but day by day, water crises have become increased. The shortage of water can be solved by following methods (El-Ghonemy 2012):

1. Transportation of water from other location.

2. Desalination of brackish water.

3. Extract of water vapors particles from atmospheric air.

The first two methods are expensive and also depend upon the regions of availability, but the third method is comparatively cheap and can be used in most of the places.

Shobhit Srivastava

shobhitsrinitkkr@gmail.com

1 Department of Mechanical Engineering, National Institute of Technology, Kurukshetra, Haryana 136119, India
Extract of water from atmospheric air can be used by one of the following methods (El-Ghonemy 2012):

1. Condense the water vapors below the dew point temperature.

2. Collection of wet from the fog.

3. Absorb the water vapors by desiccant materials from surrounding air and then regenerate them by waste heat.

The desiccant materials may be solid, liquid or composite. The desiccant materials absorb the moisture from the surrounding air and when these materials regenerate, they release the moisture in the form of water droplets.

Many attempts have been made to produce water from atmospheric air by using different desiccant materials. Kobayashi (1963) extracted water vapors from air by using adsorbent technology using modular cassettes. It was a patent technology. Abualhamayel and Gandhidasan (1997) produced $1.92 \mathrm{~kg} / \mathrm{m}^{2}$ of water by using $\mathrm{CaCl}_{2}$ as an absorbent in blackened, titled surface and single glazing box. Gordeeva et al. (1998) used new composite desiccant materials called selective water sorbent in this field. They performed their experiments in Boreskov Institute of catalysis, Novosibirsk, Russia, and the water collected from the system was 3-5 tones per day from 10 ton of dry sorbents. Gad et al. (2001) used thick corrugated cloth of different layers and dipped into $30-40 \%$ concentration of $\mathrm{CaCl}_{2}$, which produced water $1.5 \mathrm{l} / \mathrm{m}^{2}$ in a day. Kabeel (2004) extracted 1.21 water per 
square meter of glass cover by using $30 \%$ concentrated calcium chloride impregnated with sandy bed in Egypt. Furthermore, Kabeel (2007) made two glass pyramids of the same dimensions with a multi-shelf. In the first pyramid, the saw wood was kept in a bed, whereas in the second pyramid, the bed was made of cloth. Both bed saturated with $30 \%$ concentrated $\mathrm{CaCl}_{2}$. After the investigation, it was found that the cloth bed absorbs more moisture as compared to saw wood and $2.5 \mathrm{l} /\left(\right.$ day $\left.\mathrm{m}^{2}\right)$ water was produced by the system. Zheng et al. (2011) performed experiments on the ship by making two adsorption towers of the same size and capacity. In the first tower there was silica gel, while in the second tower have used composite material which consists of silica gel and $\mathrm{CaCl}_{2}$ in the ratio of 7:3, respectively. The water produced from the first tower was $0.5 \mathrm{~kg}$ from $9 \mathrm{~kg}$ of silica gel, while the productivity enhanced by $3: 4$ times that of silica gel by using composite material. William et al. (2015) collected water by using trapezoidal prism. The sides of prism were made of fiber glass. Two types of composite desiccant materials, i.e., cloth/ $\mathrm{CaCl}_{2}$ and sand $/ \mathrm{CaCl}_{2}$, were used for water production from atmospheric air using solar energy and water collected during the experiments were 2.32 and 1.23 silt/days $\mathrm{m}^{2}$, respectively. Kumar and Yadav (2015) performed experiments on solar glass desiccant box system using saw wood impregnated with different concentrations of $\mathrm{CaCl}_{2}$. The maximum production was $180 \mathrm{ml} / \mathrm{kg} /$ day for concentration $60 \%$ of $\mathrm{CaCl}_{2}$. The optimum design parameter for the maximum yield was $0.22 \mathrm{~m}$ air gap height, $30^{\circ}$ inclination angle and $3 \mathrm{~mm}$ glass thickness. In the same setup, Kumar and Yadav (2016) produced water from the composite desiccant material of $\mathrm{CaCl}_{2} /$ floral foam and the yield was $0.35 \mathrm{ml} / \mathrm{cm}^{3} /$ day. The cost analysis of solar glass desiccant box system was also carried out by the author. Wang et al. (2017a) performed experiments on eight sorbent composites with four matrixes of ACF, E, ES and SC and two salts of $\mathrm{CaCl}_{2}$ and $\mathrm{LiCl}$ of each having $30 \%$ concentration. After the investigation, it was concluded that ACF with $\mathrm{LiCl}$ has the best water uptake capability and also has the best desorption capacity $(0.6 \mathrm{~g} / \mathrm{g})$ at $77{ }^{\circ} \mathrm{C}$ and $20 \% \mathrm{RH}$. Kabeel et al. (2016) used thermoelectric technology (TE) in this field so that evaporation rate can be increased and hence increases the efficiency of the system. The productivity of the system was $3.9 \mathrm{l} / \mathrm{h} / \mathrm{m}^{2}$. Mohamed (2017) developed the mathematical model for regeneration process for theoretical study and found $15 \%$ improvement compared to other published models in theoretical study. In addition, the author also studied the initial desiccant concentration, solution mass, bed materials of wet desiccant system. The productivity of the system was $3 \mathrm{l} /$ day $\mathrm{m}^{2}$ fresh water for $30 \%$ solution concentration. Wang et al. (2017b) used active carbon felt with $\mathrm{LiCl}$ for the water production from semi-opened system. Sorption and desorption have been carried out at different weather conditions, and the maximum $14.7 \mathrm{~kg}$ of water was collected by using $40.8 \mathrm{~kg}$. Kim et al. (2017) used metal organic framework microcrystalline powder MOF-801 $\left[\mathrm{Zr}_{6} \mathrm{O}_{4}(\mathrm{OH})_{4}(\text { fumarate })_{6}\right]$ for water production from atmospheric air under weather condition of South Arabia. When the humidity was less than $20 \%$, the productivity of the system was $2.81 / \mathrm{kg}$ of MOF. Tu et al. (2018) reviewed the different methods of water production from atmospheric air including radiative cooling, adsorption-based water production and solar distilling. The economic hindrance and their solution also have been discussed in this article. Talaat et al. (2018) used cloth layer impregnated with $\mathrm{CaCl}_{2}$ solution to extract water vapors from atmospheric air by solar-powered portable apparatus. Double faced conical type absorber had been used to absorb the moisture during the night and during the day time this absorber had been covered tightly with conical transparent surface. The output of the system varied from 0.3295 to $0.6310 \mathrm{~kg} / \mathrm{m}^{2} /$ day.

Most of the work by different investigators through experimentally or theoretically analysis on water production by using solar energy, but very few of them worked on the cost analysis, which is the main hindrance in solar energy application-based experiments due to high cost of apparatus. In the presented manuscript, the author carried out cost of water production by using solid and composite desiccant materials through Scheffler reflector. For this, author first performed experiments at different days of months and produced water and after that economic analysis was carried out.

\section{Experimental setup}

The setup for investigation is installed at National Institute of Technology, Kurukshetra, Haryana, India (29 $58^{\prime}$ (latitude) North $76^{\circ} 53^{\prime}$ (longitude). There are two main parts of the experimental setup:

1. Scheffler reflector

2. Receiver box

1. Scheffler reflector

The Scheffler reflector is a fixed focus type concentrator. It is a small section of paraboloid which focuses the Sun's light at a fixed point. A newly designed Scheffler reflector of surface area $1.54 \mathrm{~m}^{2}$ is used for experimental investigation. The reflector frame consists of several aluminum reflective sheets attached to frame. The reflector tracks the Sun throughout the day about North-South direction parallel to Earth's axis. Seasonal tracking from East to West can also be achieved by seasonal adjustment screw.

2. Receiver box 
(a)

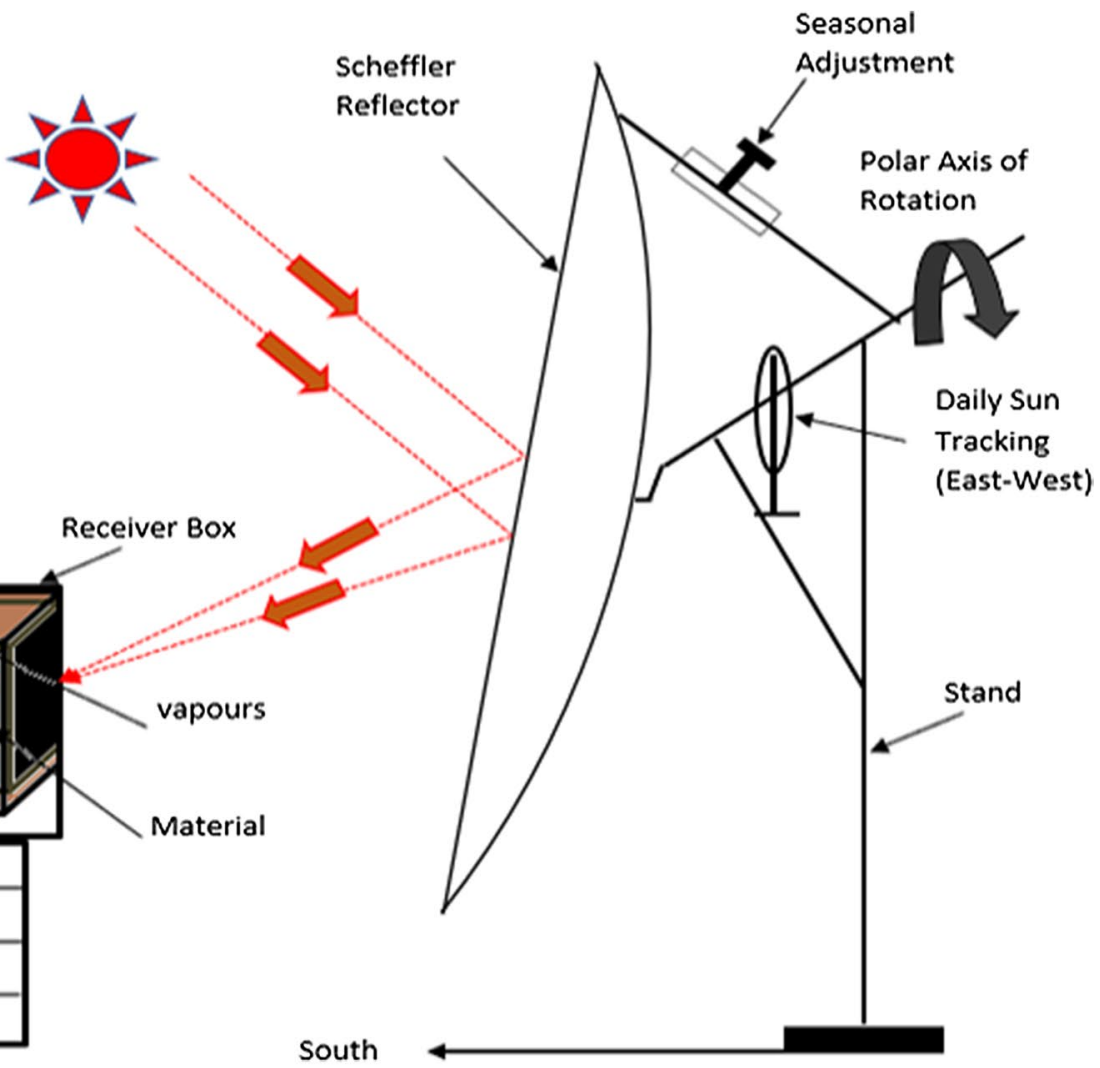

(b)

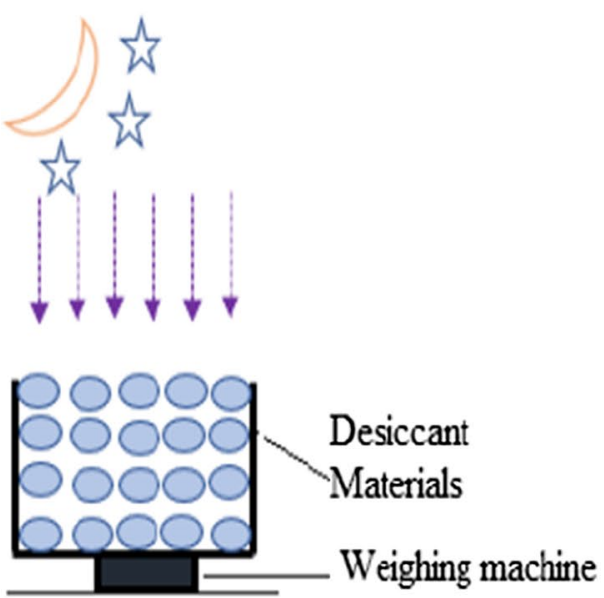

1. Adsomtion Process

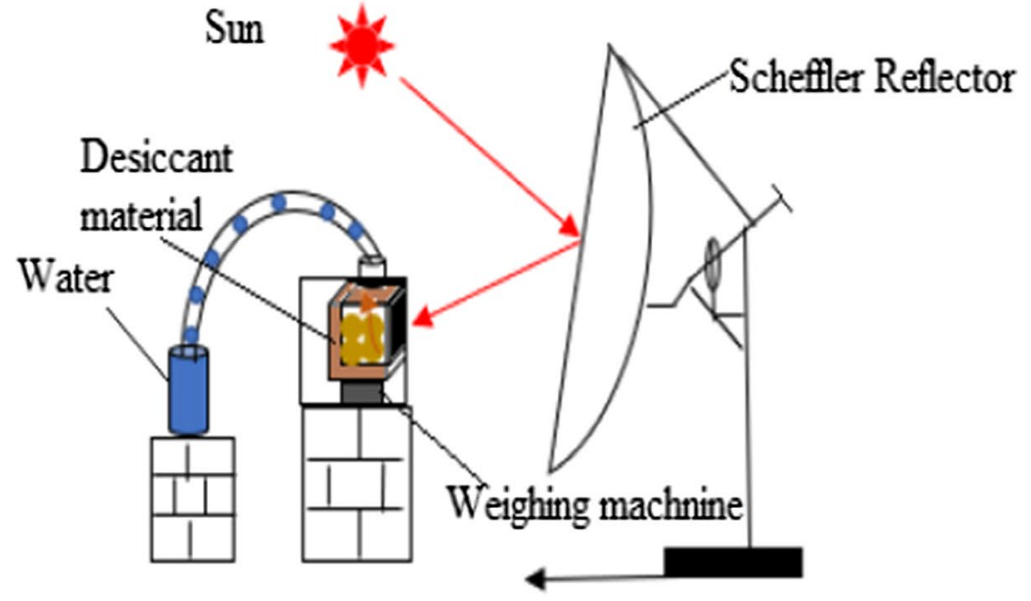

2. Water production

Fig. 1 a Schematic diagram of experimental setup and $\mathbf{b}$ Schematic diagram of process of water production from atmospheric air at night and day time

The box is made of mild steel sheet of dimensions $11 \mathrm{~cm} \times 13 \mathrm{~cm} \times 7 \mathrm{~cm}$. In this box, the materials are placed during the regeneration process in day time. The box is covered with another box having insulating material of glass wool between them except from front side. On the upper side of box, a condenser pipe is fitted in 
Fig. 2 Pictorial view of experimental setup
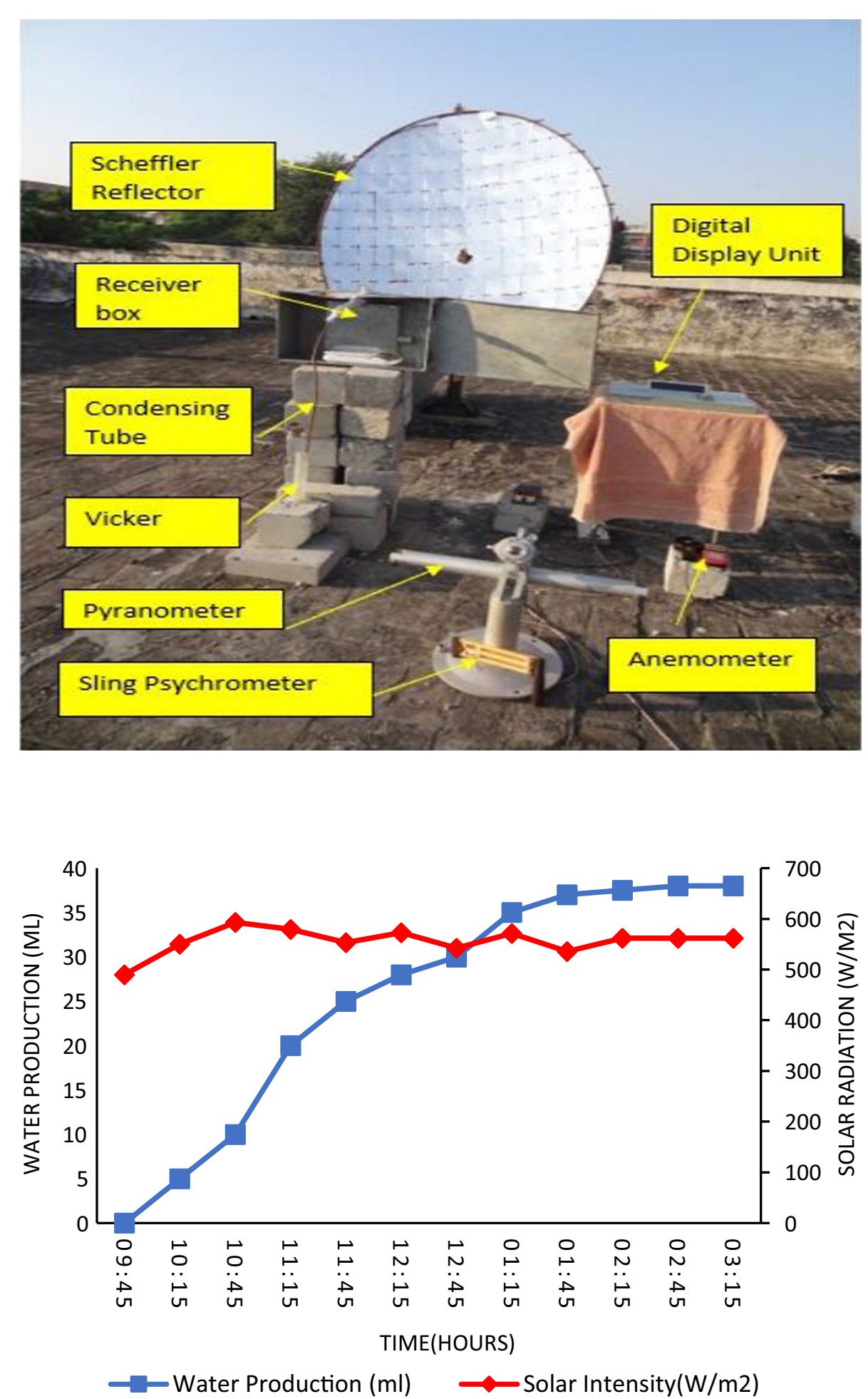

Fig. 3 Variation of water production with solar intensity w.r.t. time for activated alumina

which water vapors are condensed and converted into water droplets. The other end kept into vicker to collect water droplets. The receiver is situated at a distance of $0.83 \mathrm{~m}$ and at a height of $0.73 \mathrm{~m}$ from the Scheffler reflector.

\section{Experimental procedure}

The water production from atmospheric air is investigated in two steps. In the first step, adsorption/absorption process takes place at night. In this process, the material adsorbed 
Fig. 4 Variation of water w.r.t. time for molecular sieve production with solar intensity

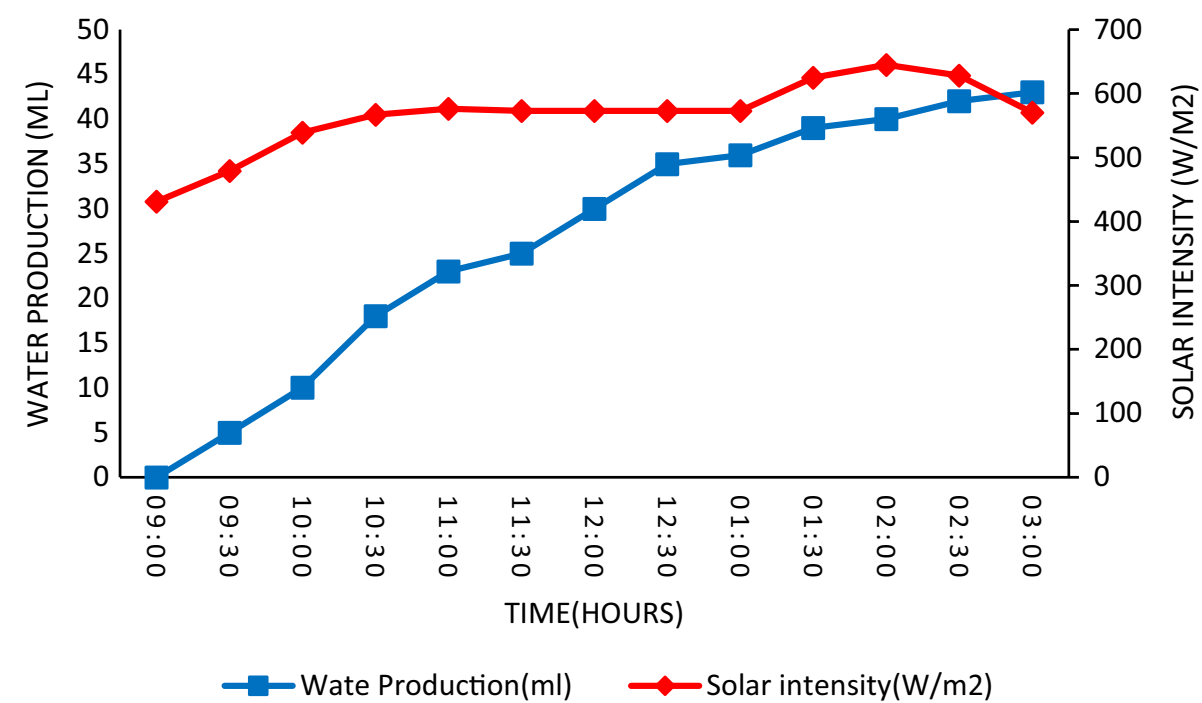

Fig. 5 Variation of water production with solar intensity w.r.t. time for silica gel

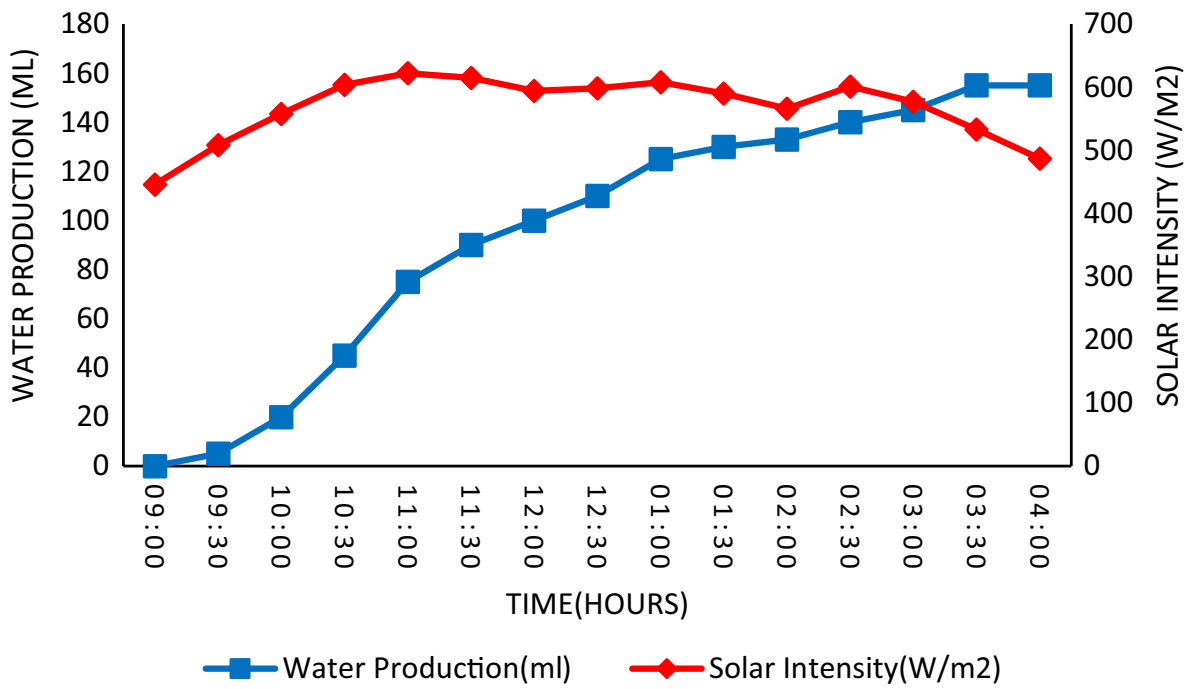

the moisture from atmospheric air due to vapor pressure difference between desiccant surface and atmospheric air. In the second stage, regeneration followed by condensation and water production takes place at day time. Figure $1 \mathrm{a}, \mathrm{b}$ shows the schematic process of water production from atmospheric air. For the measurement of solar intensity, pyranometer of range $0-2000 \mathrm{~W} / \mathrm{m}^{2}$ is used. All calibration has been taken in $30 \mathrm{~min}$ of interval after start of experiments. The pictorial view of experimental setup is shown in Fig. 2.

The water production from atmospheric air mainly depends upon the regeneration rate of the materials and it depends upon the solar intensity. To achieve the better results of water production, a newly designed Scheffler reflector of $1.54 \mathrm{~m}^{2}$ surface area is introduced, which focus the solar intensity at a fixed point. Author performed the experiments in different days of months. The results of water production by various solid desiccants and composite desiccant materials are shown in Figs. 3, 4, 5, 6, 7 and 8.

\section{Water production from solid desiccant materials}

Three solid desiccant materials, namely activated alumina, molecular sieve $13 \mathrm{X}$ and silica gel, are taken to produce water from atmospheric air. Case 1 shows the variation of rate of water production w.r.t. solar intensity for activated alumina. The total quantity of water collected from activated alumina was $38 \mathrm{ml} / \mathrm{day} / \mathrm{kg}$ (Fig. 3) and in case 2 for molecular sieve was $43 \mathrm{ml} / \mathrm{day} / \mathrm{kg}$ (Fig. 4), whereas solar intensity varies from 490 to $593 \mathrm{~W} / \mathrm{m}^{2}$ and $431-628 \mathrm{~W} / \mathrm{m}^{2}$, respectively. Initially, the water production rate was slow because the bed temperature was not too much but as the bed temperature increases the water production rate increases. 
Fig. 6 Variation of water production with solar intensity w.r.t. time for $\mathrm{LiCl} / \mathrm{River}$ Sand
Fig. 7 Variation of water production with solar intensity w.r.t. time for $\mathrm{CaCl}_{2} / \mathrm{River}$ Sand
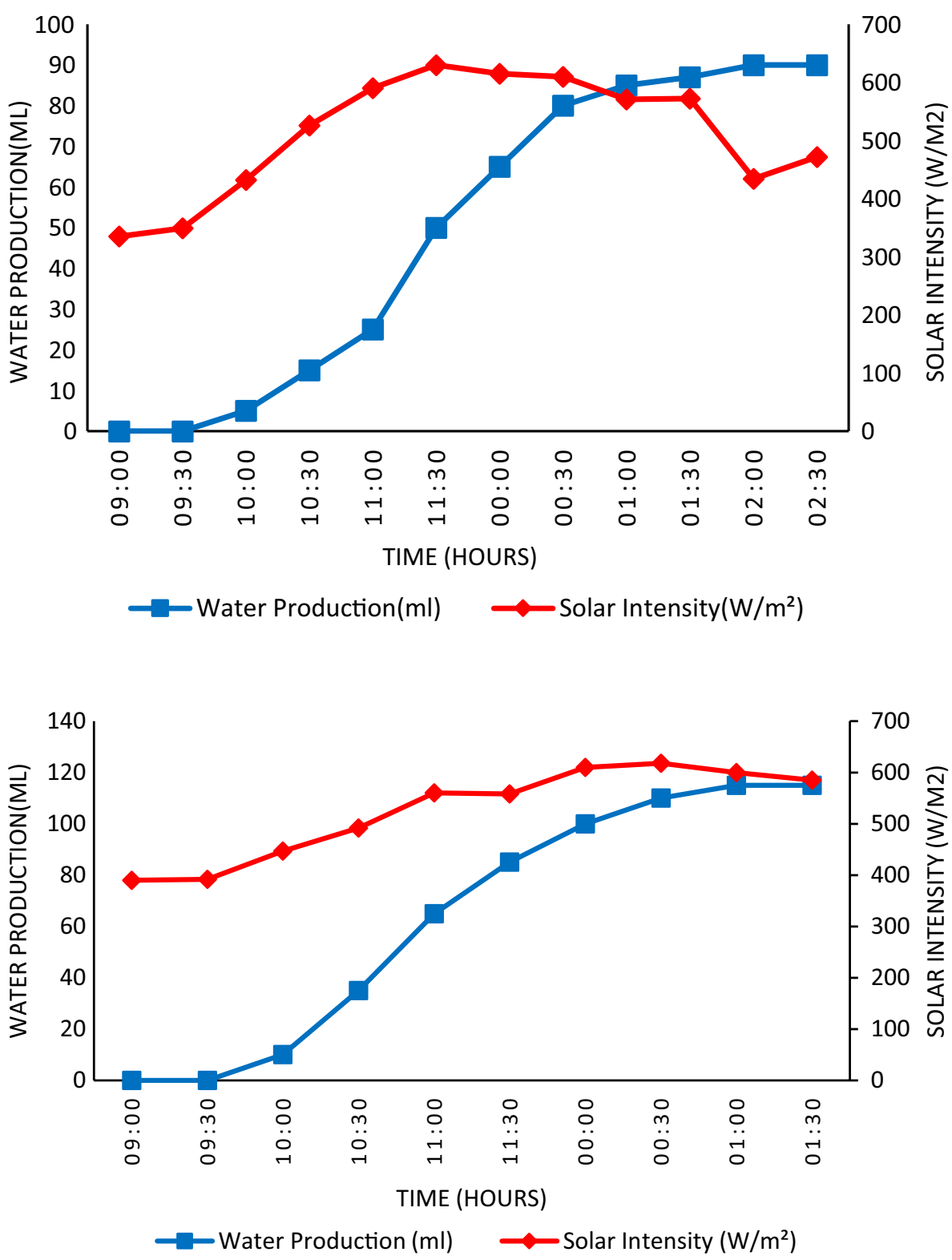

Case 1: Water production from activated alumina (15/09/2017).

Case 2: Water production from molecular sieve (18/09/17).

Case 3: Water production from the Silica gel (19/09/2017).

From Fig. 3, it has been observed that silica gel produced $155 \mathrm{ml}$ water in $7 \mathrm{~h}$ and solar intensity varies from 446 to $622 \mathrm{~W} / \mathrm{m}^{2}$.

\section{Water production from composite desiccant materials}

In case 4, case 5 and case 6 , composite desiccant materials are made by host materials of River Sand and $\mathrm{LiCl}, \mathrm{CaCl}_{2}$ and $\mathrm{LiBr}$ as a salt, one taken at a time. Figures 6, 7 and 8 show the water production with respect to time varies with solar intensity.

Case 4: Water production from $\mathrm{LiCl} / \mathrm{River}$ Sand (25/11/17).

From Fig. 6, it is observed that maximum amount of water extracted from saturated $\mathrm{LiCl} / \mathrm{River}$ Sand is $90 \mathrm{ml}$ in $5: 30 \mathrm{~h}$ when intensity varies from 335 to $630 \mathrm{~W} / \mathrm{m}^{2}$. 
Fig. 8 Variation of water production with solar intensity w.r.t. time for $\mathrm{LiBr} / \mathrm{River}$ Sand

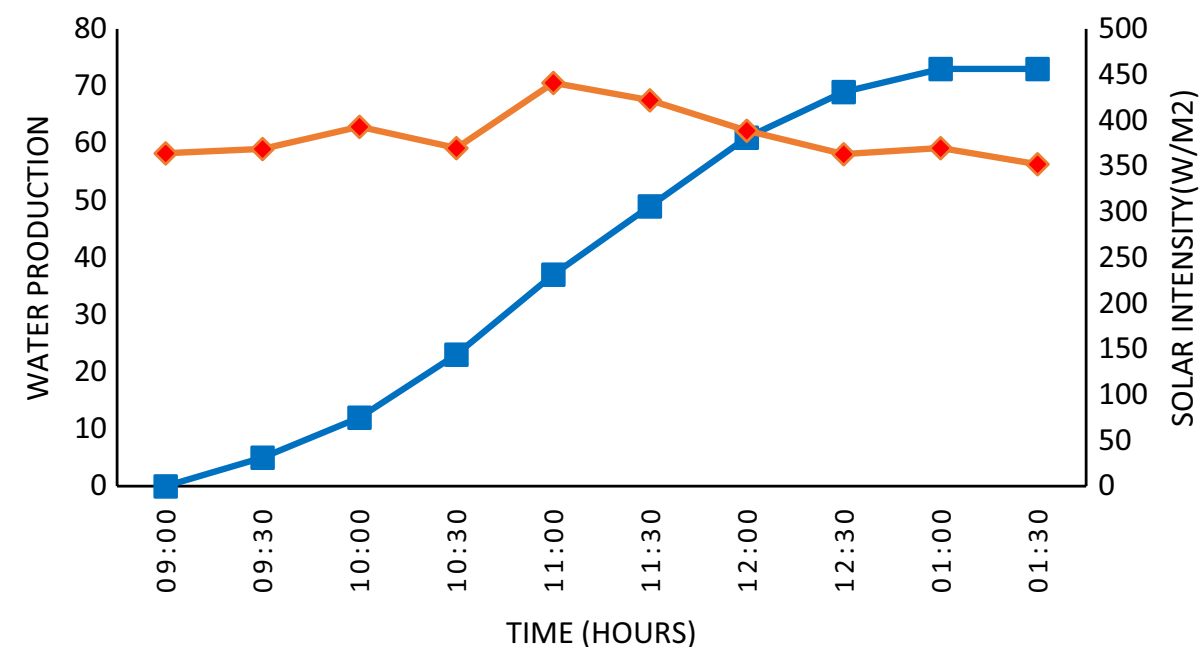

$\multimap$ Water Production $(\mathrm{ml}) \multimap$ Solar Intensity $\left(\mathrm{W} / \mathrm{m}^{2}\right)$
Table 1 Cost of different items in Indian currency

\begin{tabular}{ll}
\hline Items & Cost in Indian Rs. \\
\hline Scheffler reflector with stand & 6700 \\
Silica gel (per kg) & 250 \\
Molecular sieve (per kg) & 350 \\
Activated alumina (per kg) & 160 \\
$\mathrm{LiCl}(150 \mathrm{~g})$ & 427.50 \\
$\mathrm{CaCl}_{2}(150 \mathrm{~g})$ & 30 \\
$\mathrm{LiBr}(150 \mathrm{~g})$ & 300 \\
$\mathrm{Receiver} \mathrm{box}$ & 500 \\
Condensing pipe & 200 \\
Weighing machine & 700 \\
Insulating material & 200 \\
Paint & 150 \\
Vicker & 100 \\
Labor cost & 500 \\
Total (Rs.) & 9300 \\
\hline
\end{tabular}

Case 5: Water production from $\mathrm{CaCl}_{2} / \mathrm{River}$ Sand (27/11/17).

Case 6: Water production from $\mathrm{LiBr} / \mathrm{River}$ Sand $(03 / 12 / 17)$.

The maximum water produced in case 7 and case 8 is $115 \mathrm{ml} /$ day and $73 \mathrm{ml} /$ day, respectively, in $4: 30 \mathrm{~h}$ when the intensity varies from 390 to $618 \mathrm{~W} / \mathrm{m}^{2}$ and 363 to $422 \mathrm{~W} /$ $\mathrm{m}^{2}$, respectively.

\section{Economic analysis for water production through desiccant materials using Scheffler reflector}

The main aim of this manuscript is to find out the cost of water produced per year by different materials. The uniform procedure has been adopted for cost analysis. For the economic analysis of water production, the following terms should be known (Tiwari 1984):

1. Salvage value: the approximate selling price of a product/system after its shelf life.

It is estimated at half the initial cost.

2. Capital recovery factor: it represents a ratio calculated for the current annual value, a product/system is generating. Mathematically,

Capital recovery factor $(\mathrm{CRF})=\frac{i(1+i)^{n}}{(1+i)^{n}-1}$

3. Sinking fund factor: the term used for calculating the futuristic value depending upon the annualise cash input is called sinking fund factor. Mathematically,

Sinking fund factor $(\mathrm{SFF})=\frac{i}{\left((1+i)^{n}-1\right)}$

So, annual cost $=(1 \mathrm{st}$ annual cost of the system $)+($ annual maintenance cost $)-($ annual salvage value).

1st annual cost $=\mathrm{CRF} \times A$

Annual salvage value $=\mathrm{SFF} \times \mathrm{S}$. 


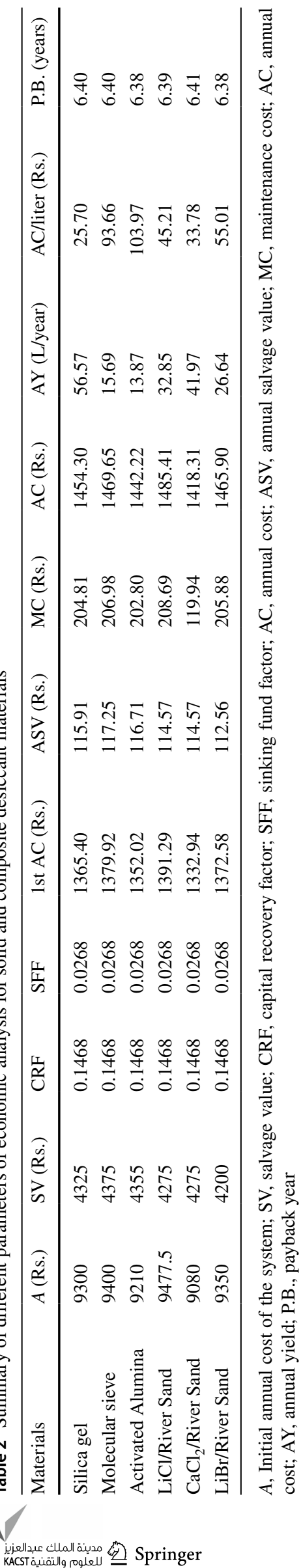

Following data are assumed for the economic calculation in all cases.

\begin{tabular}{ll}
\hline The useful life of the system $(n)$ & $=15$ years \\
Maintenance cost & $=15 \%$ of the annual cost \\
Interest rate $(i)$ & $=12 \%$ per annum
\end{tabular}

Table 1 shows the cost of different items used during investigation for water production from atmospheric air.

\section{Economic analysis of water production from Silica gel}

By the definition of salvage value,

Salvage value of the system $=$ half of initial cost $=\frac{8650}{2}=$ Rs. 4325

A $=$ Rs. 9300

$\mathrm{S}=$ Rs. 4325

$\mathrm{CRF}=0.1468$ using Eq. (1)

1st annual cost $=C R F \times A=0.1468 \times 9300=$ Rs. 1365.40

$\mathrm{SFF}=0.0268$ using Eq. (2)

Annual salvage value $=\mathrm{SFF} \times S=0.0268 \times 4325=$ Rs. 115.91

Maintenance cost $=15 \%$ of $1 \mathrm{st}$ annual cost $=$ Rs. 204.81

Annual cost $=(1365.40)+(204.81)-(115.91)=$ Rs . 1454.3

Annual yield by silica gel $=0.155 \times 365=56.57 \mathrm{l} /$ year

$$
\begin{aligned}
\text { Annual cost/liter } & =\frac{\text { annual cost }}{\text { annual yield }} \\
& =\text { Rs. } 25.70 / 1
\end{aligned}
$$

$$
\begin{aligned}
\text { Payback period } & =\frac{\text { Investment }}{\text { Cost of fresh water/day }} \\
& =\frac{9300}{3.98}=2336.68 \text { days }=6.40 \text { years }
\end{aligned}
$$

Similarly, process has been adopted for economic analysis of water production from atmospheric air using Scheffler reflector through molecular sieve, activated alumina, $\mathrm{LiCl} /$ River Sand, $\mathrm{CaCl}_{2} / \mathrm{River}$ Sand and $\mathrm{LiBr} /$ River Sand. Table 2 shows the summary of different parameters of analysis of solid and composite desiccant materials and Fig. 9 shows the annual cost of produced water per liter of these desiccant materials. 
Fig. 9 Annual cost of water per liter by different materials
120

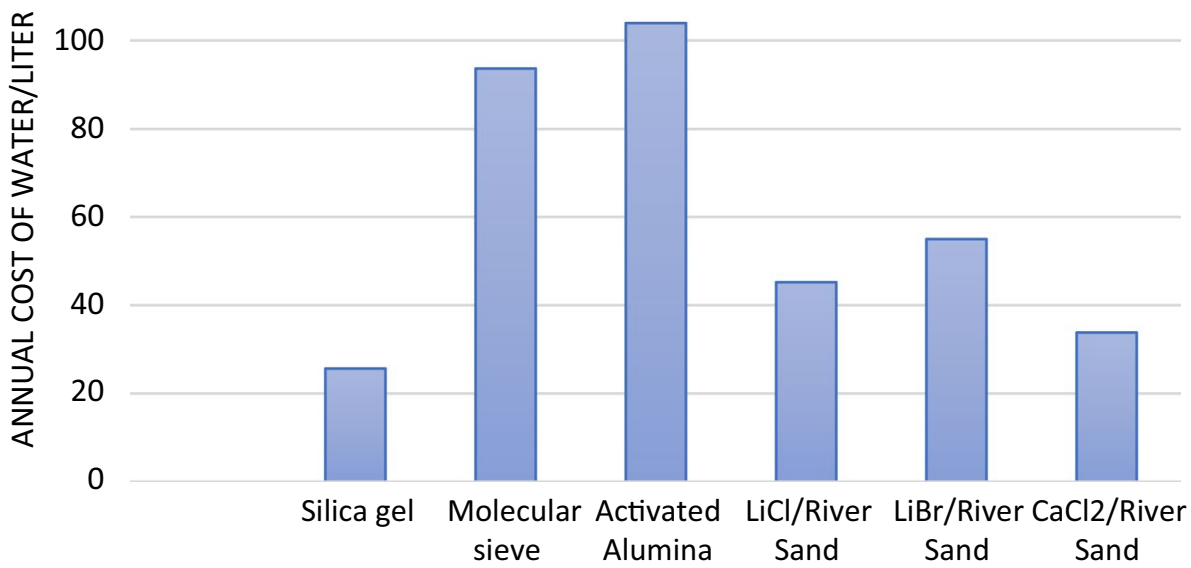

MATERIALS

\section{Conclusion}

From the above discussion and economic analysis of water production by different solid and composite desiccant materials through Scheffler reflector, the following outcomes could be drawn:

1. The maximum quantity of water and the lowest annual cost per liter are $155 \mathrm{ml} /$ day and Rs. 25.70, respectively, by silica gel compared to molecular sieve and activated alumina. However, the payback period from activated alumina is $0.31 \%$ less compared to silica gel.

2. The maximum quantity of water and the lowest annual cost per liter are $115 \mathrm{ml} /$ day and Rs. 33.78 by $\mathrm{CaCl}_{2} /$ sand compared to $\mathrm{LiCl} / \mathrm{sand}$ and $\mathrm{LiBr} / \mathrm{sand}$. But the payback period of $\mathrm{CaCl}_{2} /$ sand is more compared to $\mathrm{LiCl} /$ sand and $\mathrm{LiBr} /$ sand to $0.31 \%$ and $0.46 \%$, respectively.

3. Overall silica gel is the best economical and water-producing desiccant material compared to molecular sieve, activated alumina, $\mathrm{LiCl} / \mathrm{sand}, \mathrm{CaCl}_{2} /$ sand and $\mathrm{LiBr} /$ sand.

Open Access This article is distributed under the terms of the Creative Commons Attribution 4.0 International License (http://creativeco mmons.org/licenses/by/4.0/), which permits unrestricted use, distribution, and reproduction in any medium, provided you give appropriate credit to the original author(s) and the source, provide a link to the Creative Commons license, and indicate if changes were made.

\section{References}

Abualhamayel HI, Gandhidasan P (1997) A method of obtaining fresh water from the humid atmosphere. Desalination 113(1):51-63. https://doi.org/10.1016/S0011-9164(97)00114-8

El-Ghonemy AMK (2012) Fresh water production from/by atmospheric air for arid regions, using solar energy: review. Renew
Sustain Energy Rev 16(8):6384-6422. https://doi.org/10.1016/j. rser.2012.06.029

Gad HE, Hamed AM, El-Sharkawy II (2001) Application of a solar desiccant/collector system for water recovery from atmospheric air. Renewable Energy 22(4):541-556. https://doi.org/10.1016/ S0960-1481(00)00112-9

Gordeeva LG, Tokarev MM, Parmon VN, Aristov YuI (1998) Selective water sorbents for multiple application, 6: freshwater production from the atmosphere. React Kinet Catal Lett 65(1):153-159. https ://doi.org/10.1007/BF02475329

Kabeel AE (2004) Application of sandy bed solar collector system for extraction of water from air. In: Proceedings of the eighth international water technology. http://www.water-observatory.net/sourc es/iwtc2004/03-5.PDF. Accessed 30 Apr 2018

Kabeel AE (2007) Water production from air using multi-shelves solar glass pyramid system. Renewable Energy 32(1):157-172. https:// doi.org/10.1016/j.renene.2006.01.015

Kabeel AE, Abdulaziz Mohamed, El-said EMS (2016) Solar-based atmospheric water generator utilisation of a fresh water recovery: a numerical study. Int J Ambient Energy 37(1):68-74. https://doi. org/10.1080/01430750.2014.882864

Kim H, Yang S, Rao SR, Narayanan S, Kapustin EA, Furukawa H, Umans AS, Yaghi OM, Wang EN (2017) Water harvesting from air with metal-organic frameworks powered by natural sunlight. Science 356:430-434

Kobayashi M (1963) A method of obtaining water in arid lands. Sol Energy 7(3):93-99. https://doi.org/10.1016/0038-092X(63)90034 $-3$

Kumar M, Yadav A (2015) Experimental investigation of solar powered water production from atmospheric air by using composite desiccant material ' $\mathrm{CaCl}_{2} / \mathrm{saw}$ wood'. Desalination 367:216-222. https ://doi.org/10.1016/j.desal.2015.04.009

Kumar M, Yadav A (2016) Solar-driven technology for freshwater production from atmospheric air by using the composite desiccant material ' $\mathrm{CaCl}_{2} /$ floral foam'. Environ Dev Sustain 18(4):11511165. https://doi.org/10.1007/s10668-015-9693-3

Mohamed MH, William GE, Fatouh M (2017) Solar energy utilization in water production from humid air. Sol Energy 148:98-109. https ://doi.org/10.1016/j.solener.2017.03.066

Talaat MA, Awad MM, Zeidan EB, Hamed AM (2018) Solar-powered portable apparatus for extracting water from air using desiccant solution. Renewable Energy 119:662-674. https://doi. org/10.1016/j.renene.2017.12.050 
Tiwari GN (1984) Economic analysis of some solar energy systems. Energy Convers Manag 24(2):131-135

Tu Y, Wang R, Zhang Y, Wang J (2018) Progress and expectation of atmospheric water harvesting. Joule 2(8):1452-1475. https://doi. org/10.1016/j.joule.2018.07.015

Wang JY, Liu JY, Wang RZ, Wang LW (2017a) Experimental research of composite solid sorbents for fresh water production driven by solar energy. Appl Therm Eng 121:941-950. https://doi. org/10.1016/j.applthermaleng.2017.04.161

Wang JY, Wang RZ, Wang LW, Liu JY (2017b) A high efficient semiopen system for fresh water production from atmosphere. Energy 138:542-551. https://doi.org/10.1016/j.energy.2017.07.106

William GE, Mohamed MH, Fatouh M (2015) Desiccant system for water production from humid air using solar energy. Energy 90:1707-1720. https://doi.org/10.1016/j.energy.2015.06.125
Zheng QR, Pan QY, Jie C, Zhi HJ, Lin JM (2011) Preliminarily study of extracting water from air utilizing ship's waste heat from cylinder jacket cooling water. In: 2011 International conference on computer distributed control and intelligent environmental monitoring, pp 1632-1636. https://doi.org/10.1109/cdciem.2011.152

Publisher's Note Springer Nature remains neutral with regard to jurisdictional claims in published maps and institutional affiliations. 